\title{
Production and Blood Parameters of Holstein Cows Treated Prepartum with Sodium Monensin or Propylene Glycol
}

\author{
S. O. Juchem,† F. A. P. Santos, H. Imaizumi, A. V. Pires, and E. C. Barnabé \\ Department of Animal Science \\ Escola Superior de Agricultura Luiz de Queiroz \\ University of São Paulo, Brazil
}

\section{ABSTRACT}

Forty-five multiparous Holstein cows were assigned to one of 3 treatments in a randomized complete block design. The objective was to evaluate the effects of sodium monensin (M) and propylene glycol (PPG) during the prepartum period on performance and metabolic parameters during the late dry and first 9 wk postpartum for cows receiving $\mathrm{M}$ postpartum. Treatments were: control (C), $\mathrm{M}$ in a controlled-release capsule to deliver $335 \pm 33 \mathrm{mg} / \mathrm{d}$ for approximately $100 \mathrm{~d}$, and 300 $\mathrm{mL} / \mathrm{d}$ of PPG drenched orally. Treatments started at 35 and $21 \mathrm{~d}$ prior to the expected date of calving for cows receiving $\mathrm{M}$ and $\mathrm{PPG}$, respectively. To ensure that all treatments would be restricted to the prepartum period, C and PPG cows received a M controlled-release capsule in the first $24 \mathrm{~h}$ after calving. Prepartum propylene glycol administration increased concentrations of glucose and insulin, and decreased $\beta$-hydroxybutyrate and nonesterified fatty acids in plasma prepartum. Milk production was similarly affected by treatments. However, prepartum $\mathrm{M}$ treated cows tended to produce more $3.5 \%$ fat-corrected milk compared with control, but similar to PPG. Milk fat content and yield tended to be greater for cows that received M prepartum than for C cows, while PPG cows were similar to M and C. Prepartum administration of $\mathrm{M}$ decreased milk protein content, but no effect was observed on protein yield.

(Key words: dairy cow, transition, propylene glycol, monensin)

Abbreviation key: AST = aspartate aminotransferase, $\mathbf{C R C}=$ controlled-release capsule, $\mathbf{C}=$ control, $\mathbf{M}$ = sodium monensin, $\mathbf{P P G}=$ propylene glycol.

\footnotetext{
Received October 18, 2002.

Accepted May 21, 2003.

Corresponding author: F. A. P. Santos; e-mail: fapsanto@carpa. ciagri.usp.br.

*Research conducted under FAPESP (SP-Brazil) financial support, project numbers 98/ 04774-9 and 04769-5.

$\dagger$ Present address: Veterinary Medicine and Research Center-UC Davis. 18830 Road 112, Tulare, CA 93274.
}

\section{INTRODUCTION}

The continuous increase in milk production has created new challenges for the high-producing dairy cow, especially during the transition period. At the beginning of lactation, dairy cows have to cope with the high energy and protein demands for milk synthesis at a time when nutrient intake is low. Mobilizing energy and protein from body tissue stores and repartition of nutrients away from extramammary tissues are the primary alternatives to supply sufficient nutrients for milk production during the first weeks of lactation. Excessive body reserves, especially fat, can subject cows to a series of metabolic disorders and consequent production losses (Fourichon et al., 1999). Drackley (1998) highlighted that management of transition cows is a key step in achieving success and profitability in dairy farms.

Alternatives have been suggested to ameliorate or minimize the metabolic challenge during transition, including an increase in nutrient density of close-up dry cow diets, providing a comfortable environment that minimizes the depression in feed intake prior to calving, and including feed additives in pre- and postpartum diets. Useful feed additives would be those that promote an increase in glucose availability and a decrease in body triacylglycerol mobilization.

Propylene glycol (PPG) is a compound known for its gluconeogenic properties in ruminants (Waldo and Schultz, 1960) and has been recommended for ketosis therapy and prevention (Sauer et al., 1973). Administration of PPG improves metabolic parameters of transition cows by increasing plasma concentrations of glucose and insulin and decreasing plasma concentrations of NEFA and BHBA. Recent studies (Formigoni et al., 1996; Laranja da Fonseca et al., 1998) noted that improvements in prepartum metabolic parameters in cows receiving PPG did not improve postpartum performance.

The mode of action of sodium monensin (M) is based on modulation of rumen fermentation through microbial selection. Benefits attributed to this ionophore and of impact to transition cows include increased molar 
concentration of rumen propionate, more stable rumen environment with less fluctuation in rumen $\mathrm{pH}$, reduced rumen proteolytic activity, and increased efficiency of energy utilization within the rumen due to a decrease in methane production (Russell, 1997). Nevertheless, $\mathrm{M}$ has also been shown to cause small reductions in milk fat content (Kenelly and Lien, 1997; Van Der Werf et al., 1998) and DMI, although milk fat production generally is not affected. A decrease in DMI has been observed by some (Sauer et al., 1989; Thomas et al., 1993), but responses vary with M dose, diet composition and management conditions. The advantages of using M over PPG are cost and ease of administration (either in the diet or as a controlled-release capsule).

In contrast to studies evaluating PPG, administration of $\mathrm{M}$ to transition cows has been shown to increase milk production (Beckett et al., 1998; Duffield et al., 1999) and reduce the incidence of subclinical ketosis (Sauer et al., 1989; Duffield et al., 1998b), but its effect on blood parameters has been inconsistent.

Use of $\mathrm{M}$ is widespread in lactating cows in Brazil, whereas PPG is more commonly used as an adjuvant in ketosis therapy. The objectives of this study were to compare the effects of prepartum administration of $\mathrm{M}$ or PPG on blood biochemistry profile and on production performance through the ninth week postpartum for cows receiving $\mathrm{M}$ postpartum.

\section{MATERIALS AND METHODS}

\section{Animals and Treatments}

Forty-five multiparous Holstein cows from the Department of Animal Science dairy herd at the University of São Paulo (ESALQ-USP) were assigned to one of the three treatments. Treatments were as follows: a control (C), M in a CRC (Elanco Saúde Animal, São Paulo, Brazil) to deliver $335 \pm 33 \mathrm{mg} / \mathrm{d}$ for approximately $100 \mathrm{~d}$ (Green et al., 1999), and $300 \mathrm{~mL} / \mathrm{d}$ of PPG drenched orally. Treatments started at 35 and $21 \mathrm{~d}$ prior to the expected date of calving for cows receiving $\mathrm{M}$ and PPG, respectively, and PPG administration ended at the day prior to calving. To ensure that all treatments would be restricted to the prepartum period, $\mathrm{C}$ and PPG cows received a M CRC in the first $24 \mathrm{~h}$ after calving.

During the prepartum period, cows were housed in an open lot equipped with shade and at least $70 \mathrm{~cm}$ of feedbunk space per cow. During lactation, cows were housed in a freestall barn. Body condition score was taken at dry off, calving, and again every $14 \mathrm{~d}$ through the ninth week of lactation, following a five-point scale (Edmondson et al., 1989). Cows were milked twice daily and milk samples (a.m./p.m. composite) were collected at weekly intervals and analyzed for fat, protein, lac-
Table 1. Ingredient composition of experimental diets.

\begin{tabular}{lcc}
\hline Ingredients & Prepartum & $\begin{array}{c}\text { Early } \\
\text { lactation }\end{array}$ \\
\cline { 2 - 2 } Corn silage & 33.40 & \% D basis \\
\hline Sugar cane, ground fresh & 36.00 & 39.65 \\
Grass hay & - & 5.30 \\
Cotton seed & - & 4.90 \\
Corn grain, ground & 5.80 & 10.20 \\
Popcorn, by product & 10.00 & - \\
Citrus pulp & 3.05 & 11.65 \\
Soybean meal & 8.65 & 8.10 \\
Urea & 1.35 & 17.20 \\
Mineral and vitamin mix $^{2}$ & 1.75 & 0.35 \\
\hline
\end{tabular}

${ }^{1}$ Popcorn made from regular corn grain that did not meet the industry quality control parameters. $\left(5.6 \% \mathrm{CP}\right.$ and $1.89 \mathrm{Mcal} / \mathrm{kg} \mathrm{NE} \mathrm{N}_{\mathrm{L}} ; \mathrm{DM}$ basis).

${ }^{2}$ Prepartum mineral and vitamin mix contained (\% DM): $10.0 \%$ $\mathrm{Ca}, 7.0 \% \mathrm{P}, 1.5 \% \mathrm{Mg}, 1.5 \% \mathrm{~S}, 1650 \mathrm{mg} / \mathrm{kg}$ of $\mathrm{Fe}, 2000 \mathrm{mg} / \mathrm{kg}$ of $\mathrm{Zn}$, $700 \mathrm{mg} / \mathrm{kg}$ of $\mathrm{Cu}, 1200 \mathrm{mg} / \mathrm{kg}$ of Mn, $20 \mathrm{mg} / \mathrm{kg}$ of Se, $250,000 \mathrm{IU} / \mathrm{kg}$ of vitamin A, 90,000 IU/kg of vitamin D, and $3200 \mathrm{IU} / \mathrm{kg}$ of vitamin E. Postpartum mineral and vitamin mix contained (\% DM): $18.0 \%$ $\mathrm{Ca}, 7.5 \% \mathrm{P}, 4.0 \% \mathrm{Mg}, 2.0 \% \mathrm{~S}, 1500 \mathrm{mg} / \mathrm{kg}$ of $\mathrm{Fe}, 2500 \mathrm{mg} / \mathrm{kg}$ of $\mathrm{Zn}$, $490 \mathrm{mg} / \mathrm{kg}$ of $\mathrm{Cu}, 1870 \mathrm{mg} / \mathrm{kg}$ of $\mathrm{Mn}, 18 \mathrm{mg} / \mathrm{kg}$ of Se, $140,000 \mathrm{IU} / \mathrm{kg}$ of vitamin A, 45,000 IU/kg of vitamin D, and $730 \mathrm{IU} / \mathrm{kg}$ of vitamin E.

tose, and SNF by midinfrared spectroscopy (Bentley 2000, Bentley Instruments Inc., Chaska, MN) according to AOAC (2000), at the Milk Analyses Laboratory of the University of São Paulo (ESALQ-USP, Brazil).

Diets were formulated to meet or exceed NRC (1989) guidelines for $\mathrm{NE}_{\mathrm{L}}, \mathrm{CP}, \mathrm{NDF}, \mathrm{ADF}$, minerals, and vitamins during the pre- and postpartum periods. Cows were fed a common TMR (Table 1). Prepartum diets were adjusted for $\mathrm{NE}_{\mathrm{L}}$ and $\mathrm{CP}$ (Table 2) as suggested by Grummer (1995). Samples of TMR were composited by month, resulting in 5 samples for the prepartum period and 6 samples for the lactation period. Subsamples were dried at $105^{\circ} \mathrm{C}$ for $24 \mathrm{~h}$ to determine DM content; another subsample was dried at $55^{\circ} \mathrm{C}$ for $48 \mathrm{~h}$ and ground in a Wiley mill (1-mm mesh screen; Arthur H. Thomas Co., Philadelphia, PA) in preparation for chemical analyses. Feed samples were analyzed for DM, $\mathrm{CP}$, and fat according to AOAC (2000), and for ADF and NDF according to Van Soest et al. (1991). Mineral analyses were conducted at the Soil and Plant nutrition Laboratory at University of São Paulo (ESALQ-USP).

\section{Blood Sampling and Biochemical Analyses}

Blood samples from coccygeal vessels were collected in $5-\mathrm{mL}$ Vacuntainer tubes containing $5 \mathrm{mg}$ of potassium oxalate and $5 \mathrm{mg}$ of sodium fluoride (Vacuum II; Labnew Indústria e Comérico Ltda.; São Paulo, Brazil) on $\mathrm{d} 35$ and 21 before the expected calving date, in the first $24 \mathrm{~h}$ postpartum, and on $\mathrm{d} 7,14$, and 21 of 
Table 2. Nutrient composition of experimental diets.

\begin{tabular}{lll}
\hline & \multicolumn{2}{c}{ Diets $^{1}$} \\
\cline { 2 - 3 } Nutrients & Prepartum & $\begin{array}{l}\text { Early } \\
\text { lactation }\end{array}$ \\
\hline $\mathrm{DM}, \%$ & $33.9 \pm 0.6$ & $44.5 \pm 1.8$ \\
$\mathrm{NE}_{\mathrm{L}}{ }^{2}$ Mcal/kg of DM & $1.39 \pm 0.02$ & $1.53 \pm 0.02$ \\
Crude protein, \% & $14.8 \pm 0.4$ & $20.7 \pm 1.0$ \\
NFC, \% & $37.3 \pm 1.1$ & $38.3 \pm 1.2$ \\
Fat, \% & $2.2 \pm 0.3$ & $3.6 \pm 0.6$ \\
Ash, \% & $6.7 \pm 0.8$ & $8.1 \pm 0.2$ \\
NDF, \% & $39.0 \pm 1.1$ & $29.4 \pm 0.4$ \\
$\mathrm{ADF}, \%$ & $24.2 \pm 0.6$ & $19.7 \pm 0.6$ \\
$\mathrm{Ca}, \%$ & $0.40 \pm 0.04$ & $0.81 \pm 0.07$ \\
$\mathrm{P}, \%$ & $0.32 \pm 0.01$ & $0.51 \pm 0.03$ \\
$\mathrm{~K}, \%$ & $0.99 \pm 0.06$ & $1.34 \pm 0.07$ \\
$\mathrm{Mg}, \%$ & $0.19 \pm 0.01$ & $0.31 \pm 0.01$ \\
$\mathrm{~S}, \%$ & $0.19 \pm 0.01$ & $0.25 \pm 0.01$ \\
$\mathrm{Na}, \%$ & $0.20 \pm 0.01$ & $0.30 \pm 0.08$ \\
$\mathrm{Cl}, \%$ & $0.59 \pm 0.02$ & - \\
$\mathrm{DCAD}$ (mEq/kg DM) & $57.4 \pm 11.9$ & - \\
\hline
\end{tabular}

${ }^{1}$ Average of 5 and 6 samples, for prepartum and lactation diets, respectively.

${ }^{2}$ Net energy for lactation calculated according to NRC (1989).

${ }^{3} \mathrm{NFC}, \%=100-(\mathrm{NDF}, \%+\mathrm{CP}, \%+$ fat,$\%+$ ash, $\%)$.

${ }^{4} \mathrm{DCAD}$ (Diet cation-anion difference) $\mathrm{mEq} / \mathrm{kg}=[(\mathrm{mEq} \mathrm{Na}+\mathrm{mEq}$ $\mathrm{K})-(\mathrm{mEq} \mathrm{Cl}+\mathrm{mEq} \mathrm{S})]$.

lactation. From $21 \mathrm{~d}$ before the expected calving date to parturition, blood samples were collected at 3-d intervals to minimize variation after adjustment to the effective calving date. Blood samples were collected between 0530 and $0800 \mathrm{~h}$, after the a.m. milking. During the PPG administration period, blood samples were collected 90 min after the cows were drenched.

Blood samples collected on days nearest to d 21, 14, 7 , and 3 prepartum were analyzed, and a maximum of $\pm 2 \mathrm{~d}$ of variation was accepted, otherwise the data were taken as missing values. Fifty, 59, and 58 plasma samples fit the prior description from $\mathrm{C}, \mathrm{M}$, and $\mathrm{PPG}$ treatments, respectively, and were included in the prepartum analyses. Plasma was obtained from blood after centrifugation at $2000 \times \mathrm{g}$ for $20 \mathrm{~min}$ and then stored at $-20^{\circ} \mathrm{C}$ until analyzed for glucose, insulin, NEFA, BHBA, and aspartate amino transferase (AST).

Plasma glucose was analyzed based on the glucose oxidase reaction, utilizing a biochemical analyzer YSI 2700-S BioChem (Yellow Springs Instrument Co. Inc., Yellow Springs, OH). Insulin was analyzed by radioimunoassay using a solid phase commercial kit (Insulin Coat-a-Count, Diagnostics Products Co., Los Angeles). Both BHBA (310-A UV; Sigma Diagnostics, St. Louis, $\mathrm{MO}$ ) and AST (Boehinger Mannhein, BmbH, Germany) were analyzed at the same time in a biochemical analyzer (Technicon RA 100; Technicon Instruments Co., Tarrytown, NY) at the Department of Clinical Biochemistry, College of Veterinary Medicine and Animal Science, University of São Paulo (FMVZ-USP). Plasma
NEFA concentrations were determined by a colorimetric kit (Wako Chemicals GmbH, Neuss, Germany) utilizing a protocol for microplate reader described by Johnson and Peters (1993), with modifications. Ten milliliters of plasma sample, standards, or controls was added in each well and diluted with $40 \mu \mathrm{L}$ of saline. Reagents A and B were not diluted with phosphate buffer solution, and 50 and $100 \mu \mathrm{L}$ per well of pure reagents were utilized, respectively. The microplate was incubated at $37^{\circ} \mathrm{C}$ for $10 \mathrm{~min}$.

\section{Study Design and Statistical Analyses}

One cow from treatment $\mathrm{C}$ was not included in the statistical analyses due to premature calving, resulting in an incomplete block. Therefore, 44 cows were utilized for the statistical analyses of data. Cows were assigned to treatments in a randomized complete block design. Blocks were established based on expected calving date ( $\leq 10 \mathrm{~d}$ difference for cows within the same block), milk production in the previous lactation, and BCS at dryoff.

Incidence of metabolic disorders was determined based on clinical symptoms and animal examination by a veterinarian. Cows were observed daily and examined when necessary in order to establish an appropriate diagnosis. A cow was considered to be positive for subclinical ketosis when plasma BHBA concentration was equal to or greater than $10 \mathrm{mg} / \mathrm{dL}$ (Duffield et al., 1998) in at least one blood sample. Subclinical ketosis incidence was calculated based on number of positive cows over the total number of cows per treatment.

All data were tested for normal distribution of the residues by the PROC UNIVARIATE procedure of SAS 6.11 statistical software package (SAS, 1991). The data were assumed to have residues normally distributed when the probability for Shapiro-Wilk test was equal to or greater than 0.10 , otherwise the data were submitted to mathematical transformation (Strum et al., 2000).

A weekly mean milk production obtained from daily milk records were utilized for statistical analyses. Results of plasma biochemical analyses from d 35 before expected day of calving were used for covariate adjustment of data during analyses of blood metabolites. The effect of block was included in the model as a random effect. Production performance and blood biochemistry data were analyzed as repeated measures (Littell et al., 1998) using the MIXED procedure of SAS (1991), according to the following model:

$$
\mathrm{Y}_{\mathrm{ijkl}}=\mu+\mathrm{T}_{\mathrm{i}}+\mathrm{SD}_{\mathrm{j}}+(\mathrm{T} \times \mathrm{SD})_{\mathrm{ij}}+\mathrm{B}_{\mathrm{k}}+\mathrm{C}_{\mathrm{l}}+\mathrm{E}_{\mathrm{ijkl}}
$$

where: 


$$
\begin{aligned}
\mathrm{Y}_{\mathrm{ijkl}} & =\text { observation, } \\
\mu & =\text { overall mean, } \\
\mathrm{T}_{\mathrm{i}} & =\text { treatment effects, } \\
\mathrm{SD}_{\mathrm{j}} & =\text { sample day effects, } \\
(\mathrm{T} \times \mathrm{SD})_{\mathrm{ij}} & =\text { interaction between } \mathrm{T}_{\mathrm{i}} \text { and } \mathrm{SD}_{\mathrm{j}}, \\
\mathrm{B}_{\mathrm{k}} & =\text { block effects, } \\
\mathrm{C}_{\mathrm{l}} & =\text { covariate effect, and } \\
\mathrm{E}_{\mathrm{ijkl}} & =\text { residual error }
\end{aligned}
$$

The covariance structure utilized was the first-order autoregressive for the milk production data and the first-order ante-dependence for other parameters.

Blood biochemistry data were analyzed separately for the pre- ( -21 to $-3 \mathrm{~d}$ ) and postpartum (0 to $21 \mathrm{~d}$ ) periods following the same model described above. Separate analyzes made possible visualization of treatment $\times$ time interactions within each period, treatment effects (prepartum), and possible residual effect on postpartum period independently.

Differences with $P \leq 0.05$ were considered significant and $P \leq 0.15$ were considered a tendency. All data shown are least square means.

\section{RESULTS}

After adjustment for calving date, prepartum treatment with $\mathrm{M}$ and $\mathrm{PG}$ started at $35.7 \pm 1.7$ and 21.0 $\pm 2.0 \mathrm{~d}$ prior to actual calving date, respectively. The average number of days dry was similar $(P=0.44)$ for $\mathrm{C}, \mathrm{M}$, and PPG treated cows, and averaged $63.0 \pm 2.7$, $79.0 \pm 17.5$, and $62.1 \pm 2.3 \mathrm{~d}$, respectively.

The average days pre- and postpartum when blood samples were collected did not differ among the 3 treatment groups $(P=0.95)$.

Cows treated with PPG had higher plasma glucose and insulin concentrations during the prepartum period $(P<0.01)$. A treatment $\times$ week interaction was observed for postpartum plasma glucose concentrations $(P=0.03)$ with cows in the $\mathrm{C}$ group having higher concentrations than M and PPG at parturition (Table 3 and Figure 1). As parturition approached, differences in insulin across PPG and other groups decreased, but no treatment $\times$ week interaction during the pre- or postpartum periods was observed (Table 3 and Figure 2). Plasma insulin concentrations in all cows decreased similarly as parturition approached and were not different during the first $3 \mathrm{wk}$ of lactation.

Administration of PPG lowered prepartum plasma NEFA (Figure 3) and BHBA (Figure 4) concentrations $(P<0.01)$, while cows receiving $\mathrm{M}$ tended to have higher plasma NEFA $(P=0.06)$ during lactation. Plasma NEFA and BHBA increased at parturition in all cows, and levels were not different across treatment groups (Table 3).
Plasma AST activity was higher for $\mathrm{C}$ cows during the prepartum period $(P<0.01)$, but all values were extremely low (Kaneko, 1989).

No cases of milk fever and displacement of abomasum were observed during the evaluation period, which agrees with earlier farm records. Subclinical ketosis incidences were $16.3,31.1$, and $13.3 \%$ for $\mathrm{C}$, M, and PPG, respectively, and were similar across treatments. Mean BCS at dry off (3.76, 3.75, and 3.80) and calving (3.72, 3.70, and 3.62) were similar for C, M, and PPG, respectively (treatment effect, $P=0.30$; treatment $\times$ week interaction effect, $P=0.84$ ). No difference was observed for changes in BCS, and mean BCS at $56 \mathrm{~d}$ of lactation were $3.26,2.97$, and 3.15 , for $\mathrm{C}$, M, and PPG, respectively.

Prepartum treatment with M or PPG had no effect on milk production during the first 9 wk postpartum (Table 4). However, M-treated cows tended to produce more $3.5 \%$ FCM than cows in the $\mathrm{C}$ group $(P=0.15)$ because they tended to have higher milk fat content $(P$ $=0.06)$ and yield $(P=0.10)$. Milk protein content, but not milk protein yield, was lower $(P<0.01)$ for M treated cows. Concentration and yield of SNF was similar for all 3 treatment groups, although cows receiving $\mathrm{M}$ or PPG prepartum had lower $(P<0.01)$ concentrations of lactose in milk than $\mathrm{C}$ cows.

\section{DISCUSSION}

\section{Blood Biochemistry Profile}

The incidence of metabolic and infections diseases during early lactation are greater than any other period, and these may negatively affect milk production (Fourichon et al., 1999). Although the signs of metabolic diseases are primarily observed during early lactation, a relationship to prepartum metabolic status may exist. Improving metabolic condition during the prepartum period might result in greater DMI, which has been shown to favor postpartum DMI (Grummer, 1995).

In the present study we evaluated 2 compounds that have been shown to improve metabolism (Studer et al., 1993; Duffield et al., 1998a) and/or production (Beckett et al., 1998; Laranja da Fonseca et al., 1998; Duffield et al., 1999) traits in dairy cows. Furthermore, we attempted to determine if milk production traits and postpartum energy metabolism was related to prepartum metabolic status.

At the beginning of the trial ( $35 \mathrm{~d}$ prior to calving), metabolic status was similar across treatments (Table 5), and no difference was observed for all blood parameters evaluated.

Plasma concentration of glucose, insulin, and BHBA were similar during lactation (Table 3) demonstrating the lack of residual effect of M or PPG treatment prepar- 
Table 3. Least square means for plasma concentrations of metabolic parameters in dairy cows treated with sodium monensin or propylene glycol.

\begin{tabular}{|c|c|c|c|c|c|c|}
\hline \multirow[b]{2}{*}{ Parameter } & \multicolumn{3}{|c|}{ Treatments $^{1}$} & \multirow[b]{2}{*}{ SEM } & \multicolumn{2}{|c|}{$\operatorname{Pr}>\mathrm{F}^{2}$} \\
\hline & $\mathrm{C}$ & M & PPG & & TRT & $\mathrm{TRT} \times \mathrm{W}$ \\
\hline \multicolumn{7}{|l|}{ Glucose, $\mathrm{mg} / \mathrm{dL}$} \\
\hline Prepartum & $64.2^{\mathrm{b}}$ & $64.5^{\mathrm{b}}$ & $69.6^{\mathrm{a}}$ & 1.5 & $<0.01$ & 0.59 \\
\hline Postpartum & 62.1 & 62.3 & 61.2 & 1.3 & 0.71 & 0.03 \\
\hline \multicolumn{7}{|c|}{ Insulin, $\mu \mathrm{IU} / \mathrm{mL}$} \\
\hline Prepartum & $8.86^{\mathrm{b}}$ & $9.41^{\mathrm{b}}$ & $12.45^{\mathrm{a}}$ & 0.58 & $<0.01$ & 0.09 \\
\hline Postpartum $^{3}$ & 7.98 & 8.58 & 8.14 & 0.42 & 0.58 & 0.86 \\
\hline \multicolumn{7}{|l|}{ NEFA, $\mu \mathrm{Eq} / \mathrm{L}$} \\
\hline Prepartum $^{3}$ & $260^{\mathrm{a}}$ & $262^{\mathrm{a}}$ & $187^{\mathrm{b}}$ & 28 & $<0.01$ & 0.45 \\
\hline Postpartum $^{4}$ & $455^{\mathrm{B}}$ & $556^{\mathrm{A}}$ & $475^{\mathrm{B}}$ & 36 & 0.06 & 0.51 \\
\hline \multicolumn{7}{|l|}{ BHBA, mg/dL } \\
\hline Prepartum $^{3}$ & $3.63^{\mathrm{a}}$ & $3.72^{\mathrm{a}}$ & $2.83^{\mathrm{b}}$ & 0.18 & $<0.01$ & 0.24 \\
\hline Postpartum $^{3}$ & 4.97 & 5.43 & 5.37 & 0.30 & 0.70 & 0.68 \\
\hline \multicolumn{7}{|l|}{ AST, IU/L ${ }^{5}$} \\
\hline Prepartum $^{3}$ & $22.03^{\mathrm{a}}$ & $19.62^{\mathrm{b}}$ & $18.53^{\mathrm{b}}$ & 0.74 & $<0.01$ & 0.88 \\
\hline Postpartum $^{6}$ & 24.57 & 26.45 & 24.67 & 1.00 & 0.36 & 0.68 \\
\hline
\end{tabular}

${ }^{\mathrm{a}, \mathrm{b}}$ Different low-case superscripts within the same row differ $(P \leq 0.05)$.

${ }^{\mathrm{A}, \mathrm{B}}$ Different uppercase superscripts within the same row tended to differ $(P \leq 0.15)$.

${ }^{1} \mathrm{C}=$ Control, $\mathrm{M}=$ sodium monensin, and $\mathrm{PPG}$ = propylene glycol.

${ }^{2} P$ value for the effects of treatment (TRT) and treatment by week interaction (TRT $\times \mathrm{W}$ ).

${ }^{3} P$ values obtained through transformed data $(\log 10)$.

${ }^{4} P$ values obtained through transformed data (square root).

${ }^{5} \mathrm{AST}=$ Aspartate amino transferase activity.

${ }^{6} P$ values obtained through transformed data (1/AST).

tum on blood biochemistry postpartum in lactating cows when $\mathrm{M}$ is included in the diet postpartum. The increase in prepartum plasma glucose (Figure 1) when cows were administered PPG demonstrates the glucogenic capacity of this compound as reported previously (Studer et

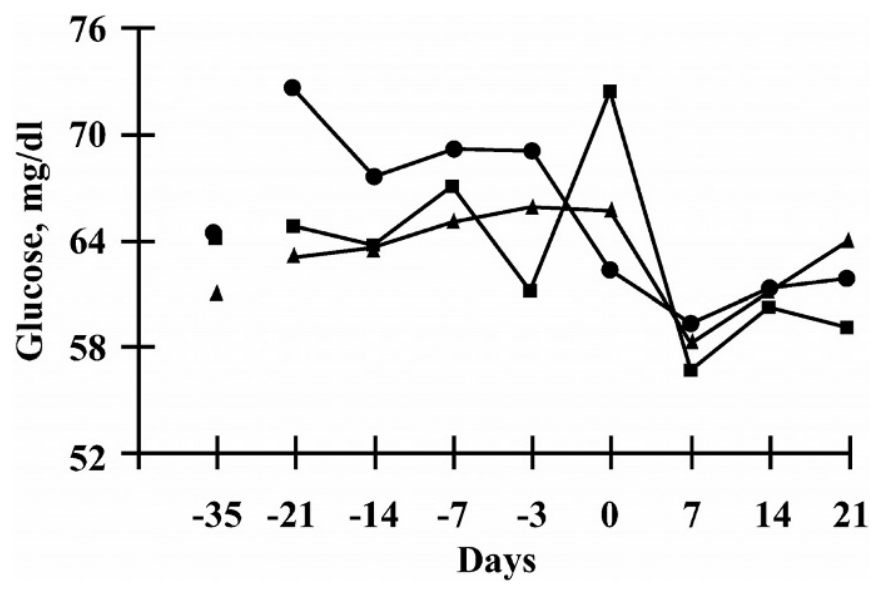

Figure 1. Plasma concentrations of glucose for cows in the control (C; - - - ), sodium monensin ( $\mathrm{M} ;-\mathbf{\Delta}-)$, and propylene glycol (PPG; - - treated groups. Day 0 represents the day of calving. Mean glucose levels at prepartum were greater for PPG treated cows $(P<0.01)$. There was an effect of treatment $\times$ week interaction $(P=$ $0.03)$ during the postpartum period, and glucose concentrations at calving were higher for $\mathrm{C}$ than $\mathrm{M}$ and PPG groups. Pooled SEM = 1.5 and 1.3 for pre- and postpartum periods, respectively. al., 1993; Grummer et al., 1994). Furthermore, as a result of increased plasma glucose, a concomitant increase in plasma insulin was also observed in cows treated with PPG.

Administration of $M$ results in specific changes in ruminal VFA molar proportions, basically an increase in propionate (Sauer et al., 1989; Ramanzin et al., 1997)

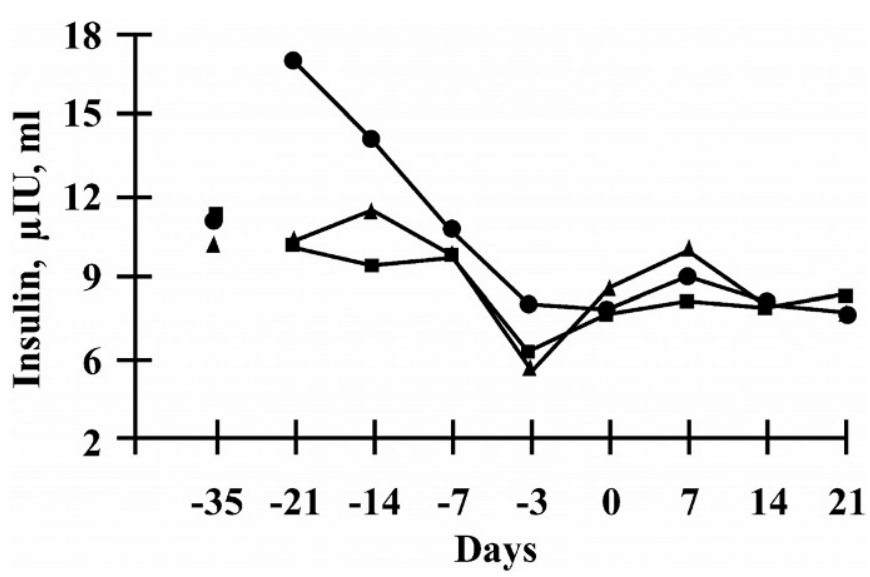

Figure 2. Plasma concentrations of insulin for cows in the control $(\mathrm{C} ;-\mathbf{-}-)$, sodium monensin $(\mathrm{M} ;-\mathbf{\Delta}-)$, and propylene glycol (PPG; - - treated groups. Day 0 represents the day of calving. Mean prepartum plasma concentrations of insulin were greater for PPG group $(P<0.01)$. Pooled SEM $=0.58$ and 0.42 for pre- and postpartum periods, respectively. 


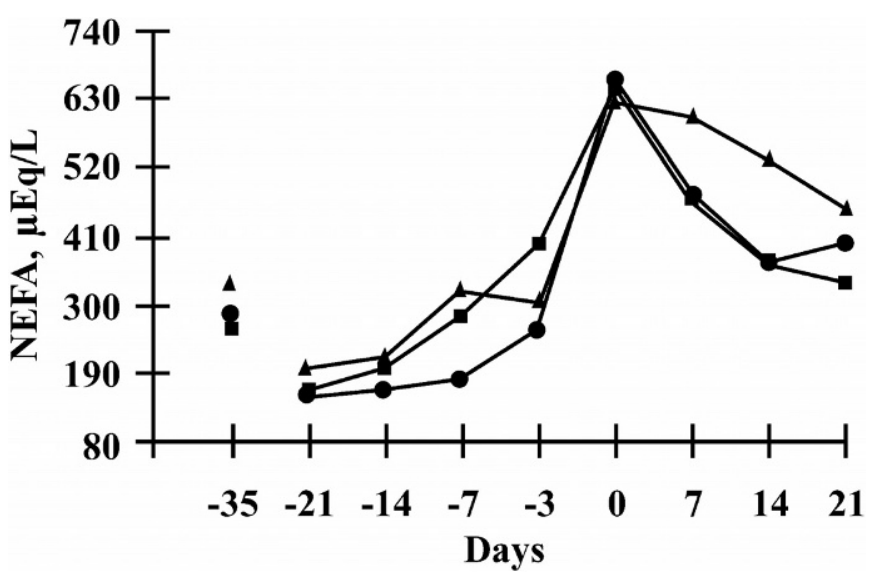

Figure 3. Plasma concentrations of NEFA for cows in the control (C; - - - ), sodium monensin ( $\mathrm{M} ;-\mathbf{\Delta}-)$, and propylene glycol (PPG; - - treated groups. Day 0 represents the day of calving. Mean prepartum plasma concentrations were lower for PPG $(P<$ $0.01)$, while during postpartum $\mathrm{M}$ tended to show higher values $(P$ $=0.06$ ). Pooled SEM $=28$ and 36 for pre- and postpartum period, respectively.

and a decrease in butyrate concentrations (Green et al., 1999), suggesting a potential benefit of this rumen fermentation modulator on energy metabolism. The increase in propionate concentration is expected to increase plasma concentration of glucose and insulin. Interestingly, in this study as well as others (Sauer et al., 1989; Ramanzin et al., 1997), the effect of M on glucose and insulin was not observed. Green et al. (1999) and Duffield et al. (1998a) detected higher blood glucose concentrations in M-treated cows during lactation, but

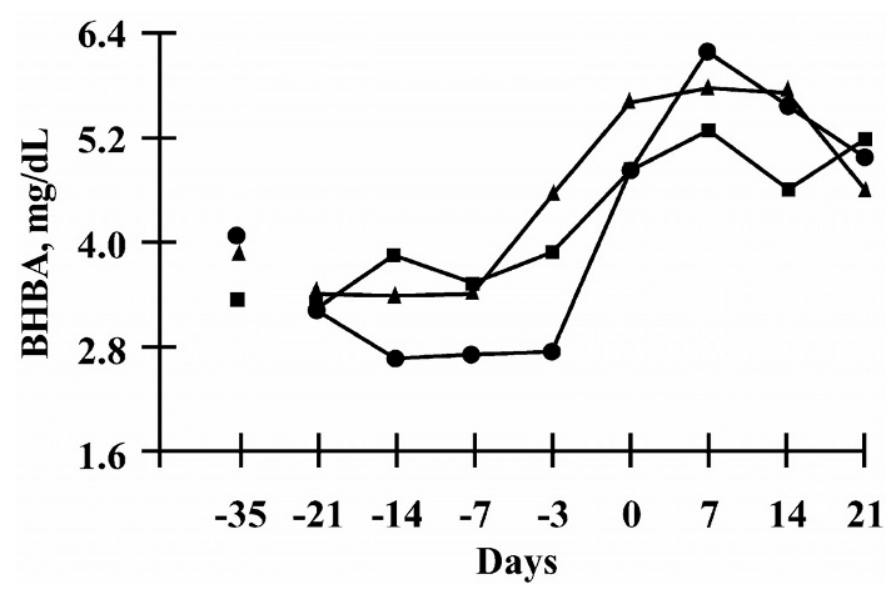

Figure 4. Plasma concentrations of BHBA for cows in the control (C; - - ), sodium monensin ( $\mathrm{M} ;-\mathbf{-}-)$, and propylene glycol (PPG; - - - treated groups. Propylene glycol treated cows showed lower plasma concentrations of BHBA during the prepartum period $(P<0.01)$. Day 0 represents the day of calving. Pooled $\mathrm{SEM}=0.18$ and 0.30 for pre- and postpartum periods, respectively. not during the prepartum period. Monensin favors glucose concentrations and other blood constituents through modification of ruminal microbial populations reflected by changes in fermentation end products. However, the effects of $\mathrm{M}$ on rumen fermentation and blood constituents are also dependent upon diet composition and rumen environment, which may partially explain the inconsistency of results among trials. While PPG effect on blood glucose and insulin is acute and easily detected in single sampling protocol, $\mathrm{M}$ mediated alterations in blood constituents are expected to be smoother and feeding related, so it may require more frequent sampling to detect differences and effects on insulin may not be detected because of diurnal variation. The limited data available regarding the effects of $\mathrm{M}$ on blood insulin agrees with our findings, and no difference has been reported for cows treated during lactation (Van Der Werf et al., 1998).

Studer et al. (1993) observed a blood glucose increase at calving in both control and PPG treated group; however, in the present trial, plasma glucose concentration at parturition increased only for $\mathrm{C}$ cows as demonstrated by the interaction between treatment and week $(P=0.03)$. Blood samples at calving, by definition, were collected in the first $24 \mathrm{~h}$ after parturition. The period that precedes calving is characterized by coordinate metabolic adaptations, some of them occurring in a very short period of time, such as the sharp rise in blood cortisol concentrations (Tucker, 1985). Therefore, it is possible that the variation in time relative to calving when samples were collected might have affected the results, and cows sampled immediately after calving could have had higher plasma glucose due to cortisolmediated gluconeogenesis, and the differences across treatments being just an effect of sampling time rather than a treatment effect itself.

Plasma NEFA (Figure 3) increases gradually as parturition approaches, reaching a peak at the day of calving, and then decreases gradually as lactation proceeds (Stephenson et al., 1997). The antilipolytic action of insulin could be beneficial to cows during the transition period. Based on NEFA dynamics, the attempts to reduce it should begin 3 to $4 \mathrm{wk}$ prepartum. Petterson et al. (1994) observed a lower response of adipose tissue cells to insulin antilipolytic action in pregnant, than in lactating and nonlactating sheep. In the present study, drenching cows with PPG was an efficient method to reduce plasma NEFA concentrations compared with cows in the $\mathrm{M}$ and $\mathrm{C}$ groups. The higher insulin and lower NEFA in PPG treated cows suggest that, in spite of the reduced response to the insulin mediated lipogenic effect (Petterson et al., 1994), insulin increases at this phase can still reduce NEFA, possibly through a negative effect on fat mobilization. Studer et al. (1993) 
Table 4. Effect of prepartum administration of propylene glycol or sodium monensin on performance of dairy cows in early lactation.

\begin{tabular}{|c|c|c|c|c|c|c|}
\hline \multirow[b]{2}{*}{ Item } & \multicolumn{3}{|c|}{ Treatment $^{1}$} & \multirow[b]{2}{*}{ SEM } & \multicolumn{2}{|c|}{$\operatorname{Pr}>F^{2}$} \\
\hline & $\mathrm{C}$ & M & PPG & & TRT & $\mathrm{TRT} \times \mathrm{W}$ \\
\hline Milk, kg/d & 31.0 & 31.6 & 31.2 & 0.9 & 0.72 & 0.92 \\
\hline $3.5 \%$ FCM, $\mathrm{kg} / \mathrm{d}$ & $29.9^{\mathrm{B}}$ & $31.3^{\mathrm{A}}$ & $30.4^{\mathrm{AB}}$ & 0.9 & 0.15 & 0.57 \\
\hline \multicolumn{7}{|l|}{ Milk fat } \\
\hline$\%^{3}$ & $3.27^{\mathrm{B}}$ & $3.46^{\mathrm{A}}$ & $3.37^{\mathrm{AB}}$ & 0.08 & 0.06 & 0.83 \\
\hline $\mathrm{g} / \mathrm{d}^{4}$ & $1016^{\mathrm{B}}$ & $1083^{\mathrm{A}}$ & $1039^{\mathrm{AB}}$ & 87 & 0.10 & 0.45 \\
\hline \multicolumn{7}{|l|}{ Milk protein } \\
\hline$\%$ & $3.02^{\mathrm{a}}$ & $2.92^{\mathrm{b}}$ & $3.02^{\mathrm{a}}$ & 0.03 & $<0.01$ & 0.99 \\
\hline $\mathrm{g} / \mathrm{d}$ & 935 & 915 & 923 & 15 & 0.56 & 0.86 \\
\hline \multicolumn{7}{|l|}{ Solids not fat } \\
\hline$\%$ & 11.77 & 11.77 & 11.72 & 0.08 & 0.87 & 0.96 \\
\hline $\mathrm{g} / \mathrm{d}$ & 3652 & 3696 & 3621 & 61 & 0.60 & 0.63 \\
\hline Lactose, \% & $4.72^{\mathrm{a}}$ & $4.63^{b}$ & $4.60^{\mathrm{b}}$ & 0.08 & $<0.01$ & 0.94 \\
\hline
\end{tabular}

${ }^{\mathrm{a}, \mathrm{b}}$ Different lowercase superscripts within the same row differ $(P \leq 0.05)$.

$\mathrm{A}, \mathrm{B}$ Different uppercase superscripts within the same row tended to differ $(P \leq 0.15)$.

${ }^{1} \mathrm{C}=$ Control, $\mathrm{M}=$ sodium monensin, and $\mathrm{PPG}=$ propylene glycol.

${ }^{2} P$ values for the effects of treatment (TRT) and treatment $\times$ week interaction $($ TRT $\times \mathrm{W})$.

${ }^{3} P$ values obtained through transformed data $(\log 10)$.

${ }^{4} P$ values obtained through transformed data (square root).

also observed a significant decrease in plasma NEFA concentrations prepartum and a tendency during lactation, when they supplied $1 \mathrm{~L}$ of PPG per cow per day.

The lack of effect of M on prepartum plasma NEFA concentrations agrees with others (Sauer et al. 1989), and few were able to show the antilipolytic effect of $M$ as measured by plasma NEFA concentrations. Stephenson et al. (1997) found a tendency for lower NEFA at prepartum, but no effect during the lactation when cows were treated with M. Ramanzin et al. (1997) observed a tendency for lower blood NEFA in cows receiving $\mathrm{M}$ in a high forage diet (70\%), but no effect when $\mathrm{M}$ was administered to cows fed a diet with $50 \%$ forage. Thomas et al. (1993) showed an effect of M on plasma NEFA in multiparous but not primiparous cows. These studies (Ramanzin et al., 1997; Stepehnson et al., 1997; Thomas et al., 1993) compared $\mathrm{M}$ administration starting at calving or prepartum with a control group that did not receive M. As most of differences in those studies were observed during lactation, maybe such difference could not be detected in the present trial because of the experimental design with all cows receiving $\mathrm{M}$ during the postpartum period.

In ruminants, butyrate absorbed by the rumen epithelium and NEFA mobilized from adipose tissue are the main ketogenic substrates. During periods of negative energy balance, NEFA from adipose tissue are the predominant substrate (Zammit, 1990). In addition to substrate, the concentration of blood ketones is a function of the availability of glucose and glucogenic compounds, so that NEFA can be completely oxidized prior to generating BHBA. The lower prepartum plasma BHBA concentration for the PPG treated group (Table 3 and Figure 4) was probably a consequence of both the increase in glucose and the decrease in NEFA. Although a decrease in ketosis incidence and postpartum BHBA blood levels in $\mathrm{M}$ treated cows are well documented (Sauer et al., 1989; Duffield et al., 1998b), we did not

Table 5. Least square means for plasma concentrations of metabolic parameters used for covariate adjustment $(-35 \mathrm{~d})$ of data during statistical analyses.

\begin{tabular}{|c|c|c|c|c|c|}
\hline \multirow[b]{2}{*}{ Parameter $^{3}$} & \multicolumn{3}{|c|}{ Treatments $^{1}$} & \multirow[b]{2}{*}{ SEM } & \multirow{2}{*}{$\frac{\operatorname{Pr}>F^{2}}{\text { TRT }}$} \\
\hline & $\mathrm{C}$ & M & PPG & & \\
\hline Glucose, mg/dL & 64.2 & 61.1 & 64.4 & 1.8 & 0.23 \\
\hline Insulin, $\mu \mathrm{IU} / \mathrm{mL}$ & 11.3 & 10.3 & 11.0 & 1.1 & 0.75 \\
\hline NEFA, $\mu \mathrm{Eq} / \mathrm{L}^{3}$ & 259 & 332 & 282 & 55 & 0.64 \\
\hline BHBA, mg/dL & 3.36 & 3.97 & 4.04 & 0.3 & 0.21 \\
\hline $\mathrm{AST}, \mathrm{IU} / \mathrm{L}^{3}$ & 20.1 & 22.5 & 22.7 & 1.1 & 0.16 \\
\hline
\end{tabular}

${ }^{1} \mathrm{C}=$ Control, $\mathrm{M}=$ sodium monensin, and $\mathrm{PPG}=$ propylene glycol.

${ }^{2} P$ value for treatment (TRT) effect.

${ }^{3} \mathrm{AST}=$ Aspartate amino transferase activity. 
observe an effect of prepartum M on plasma BHBA preor postpartum.

Prepartum administration of $\mathrm{M}$ did not beneficially affect plasma metabolites evaluated in our study. A number of studies have fed $\mathrm{M}$ before calving, but few provide prepartum blood chemistry data. Stephenson et al. (1997) fed M to grazing cows and reported some tendencies regarding the relationship between $\mathrm{M}$ and plasma NEFA and BHBA prepartum. Green et al. (1999) fed M prepartum and observed a significant treatment by parity effect on plasma glucose prepartum. The effect of $\mathrm{M}$ on rumen function and subsequent metabolic parameters are likely confounded with BCS, diet, and level of milk production.

\section{Milk Production and Composition}

In most studies, despite the positive effect on blood biochemistry, administration of PPG pre- and/or postpartum has not been shown to significantly affect yields of milk and milk components in lactating dairy cows (Fisher et al., 1973; Studer et al., 1993; Formigoni et al., 1996). However, Laranja da Fonseca et al. (1998) observed a small increase in milk production during the fourth and fifth weeks postpartum when cows were drenched with PPG pre- and postpartum.

Administration of $\mathrm{M}$ to transition cows has been shown to increase milk production from 0.75 to $2.8 \mathrm{~kg} /$ $\mathrm{d}$ in dairy herds producing 28 to $36 \mathrm{~kg} / \mathrm{d}$ (Phipps et al., 1995; Beckett et al., 1998; Duffield et al., 1999). Duffield et al. (1999) suggested that the beneficial effect of $M$ for dairy cows during the pre- and postpartum periods would be more pronounced when the risk for metabolic disorders such as ketosis is high. They observed a more consistent response to $\mathrm{M}$ supplementation in cows that were over conditioned prepartum, and cows considered thin showed no increase in milk yield when $M$ was supplemented. The BCS at the beginning of our study averaged 3.8 for cows in all treatments and was within the adequate range for close-up dry cows (Drackley, 1998). Similarly, changes in BCS pre- and postpartum were not exaggerated, which probably minimized the risk for metabolic disturbances during the transition period. The low incidence of subclinical ketosis in cows in the $\mathrm{C}$ group suggests that they were not at a high risk for metabolic disturbances, which might partially explain the lack of milk production response to these additives in the current study.

The positive response in milk fat production for cows receiving M reported by others (Beckett et al., 1998; Van Der Werf et al., 1998) was, in general, associated with an increase in milk production, since milk fat percentage remains unchanged or declines (Thomas et al., 1993; Phipps et al., 1995; Duffield et al., 1999). Monen- sin-treated cows tended to have higher content and yield of milk fat than $\mathrm{C}$ cows which resulted in a tendency for higher FCM production. Plasma NEFA concentrations during lactation also tended to be higher for cows supplemented with M prepartum. Although no differences in the dynamics of BCS changes were observed among treatments, we cannot completely rule out differences in body fat mobilization across treatments.

Although not measured in the present trial, DMI can be decreased in $\mathrm{M}$ supplemented cows (Thomas et al., 1993), but responses are quite inconsistent among studies (Van Der Werf et al., 1998) and within doses of M in the same trial (Thomas et al., 1993). As all groups were under the effect of $\mathrm{M}$ during lactation, we hypothesized that cows receiving $M$ prepartum experienced a slight decrease in feed intake before calving that increased body fat mobilization immediately postpartum as reflected by the tendency for elevated plasma NEFA and increased milk fat percentage. Content and yields of milk fat are usually unaffected by the feeding of PPG (Studer et al., 1993; Formigoni et al., 1996).

The similar content and yields of milk protein for PPG and $\mathrm{C}$ cows is in agreement with previously published studies (Fisher et al., 1973; Studer et al., 1993; Formigoni et al., 1996). Metabolic studies that evaluated feeding of $M$ have demonstrated its suppressive effects on ruminal proteolysis with consequent increase in nitrogen retention (Russell, 1997), which suggests a potential benefit of this feed additive on milk protein content. Nevertheless, studies have failed to demonstrate a positive effect of $\mathrm{M}$ on milk protein content (Sauer et al., 1989; Beckett et al., 1998; Duffield et al, 1999). We observed a decrease in milk protein content when $\mathrm{M}$ was supplemented during the prepartum period. Phipps et al. (1995) observed that administration of $M$ during lactation resulted in a decrease in milk protein content. Plasma BHBA and glucose during the postpartum period were not different across treatments, although plasma NEFA tended to be higher for cows receiving $\mathrm{M}$ prepartum. In order to avoid blood BHBA increase and at the same time utilize the available surplus of free fatty acids, the latter must be completely oxidized through TCA cycle, which requires glucose and other gluconeogenic substrate. Cows receiving $\mathrm{M}$ might have used more amino acids as gluconeogenic precursors, thus reducing the amino acids available to the mammary gland for milk protein synthesis.

Milk lactose content usually varies very little, although nutritional practices have been shown to have some effect on it. Generally, feeding M or PPG during lactation has no effect on content of milk lactose (Sauer et al., 1989; Ramanzin et al., 1997). 


\section{CONCLUSIONS}

Supplementation of prepartum Holstein cows with sodium monensin or propylene glycol had no effect on yields of milk during the first nine weeks of lactation, but milk composition was slightly altered.

Administration of propylene glycol prepartum improved blood metabolic parameters but not lactation performance. Our present findings suggest that earlier administration of $\mathrm{M}$ to dairy cows receiving a nutrient dense diet during transition has no positive effect on blood metabolites concentration, compared with cows that received $\mathrm{M}$ at calving.

Administration of these feed additives prepartum may not be beneficial to well-managed dairy herds with milk production around $30 \mathrm{~kg} / \mathrm{d}$.

\section{ACKNOWLEDGMENTS}

The authors wish to thank José E. P. Santos (VMTRC - UC Davis, Tulare, CA) for comments and suggestions during the course of the study, Paulo H. M. Rodrigues (College of Veterinary Medicine and Animal Science, FMVZ-USP, São Paulo, Brazil) for helping with the statistical analyses, and Elanco Saúde Animal (Brazil) for the donation of sodium monensin controlledrelease capsules. The assistance of Regina M. S. Mirandola, José M. Simas, and Maria Regina S. R. Peçanha during laboratory analyses is also appreciated. We are grateful to Carla M. Bittar Nussio, Flamarion R. Barboza, Marcos de Benn, and the dairy research farm staff for their help during the course of this study.

\section{REFERENCES}

Association of Official Analytical Chemists. 2000. Official Methods of Analysis. 17. Ed. AOAC, Gaithersburg, MD.

Beckett, S., I. Lean, R. Dyson, W. Tranter, and L. Wade. 1998. Effects of monensin on the reproduction, health, and milk production of dairy cows. J. Dairy Sci. 81:1563-1573.

Drackley, J. K. 1998. Transitional period nutrition management explored. Feedstuffs 70(6):12-16.

Duffield, T. F., D. Sandals, K. E. Leslie, K. Lissemore, B. W. Mcbride, J. H. Lumsden, P. Dick, and R. Bagg. 1998a. Effect of prepartum administration of Monensin in a controlled-release capsule on postpartum energy indicators in lactating dairy cows. J. Dairy Sci. 81:2354-2361.

Duffield, T. F., D. Sandals, K. E. Leslie, K. Lissemore, B. W. Mcbride, J. H. Lumsden, P. Dick, and R. Bagg. 1998b. Efficacy of Monesin for the prevention of subclinical ketosis in lactating dairy cows. J. Dairy Sci. 81:2866-2873.

Duffield, T. F., K. E. Leslie, D. Sandals, K. Lissemore, B. W. Mcbride, J. H. Lumsden, P. Dick, and R. Bagg. 1999. Effect of prepartum administration of monensin in a controlled-release capsule on milk production and milk components in early lactation. J. Dairy Sci. 82:272-279.

Edmondson, A. J., I. J. Lean, L. Weaver, T. Farver, and G. Webster. 1989. A body condition scoring chart for Holstein dairy cows. J. Dairy Sci. 72:68-78.

Fisher, L. J., J. D. Erfle, G. A. Lodge, and F. D. Sauer. 1973. Effects of propylene glycol or glycerol supplementation of the diet of dairy cows on feed intake, milk yield and composition, and incidence of ketosis. Can. J. Anim. Sci. 53:289-296.

Formigoni, A., M. C. Cornil, A. Prandi, A. Mordenti, A. Rossi, D. Portetelle, and R. Renaville. 1996. Effect of propylene glycol supplementation around parturition on milk yield, reproduction performance and some hormonal and metabolic characteristics in dairy cows. J. Dairy Res. 63:11-24.

Fourichon C., H. Seegers, N. Bareille, and F. Beaudeau. 1999. Effects of disease on milk production in the dairy cow: A review. Prev. Vet. Med. 41:1-35.

Green, B. L, B. W. Mcbride, D. Sandals, K. E. Leslie, R. Bagg, and P. Dick. 1999. The impact of a monensin controlled-release capsule on subclinical ketosis in the transition dairy cow. J. Dairy Sci. 82:333-342.

Grummer, R. R. 1995. Impact of changes in organic nutrient metabolism on feeding the transition dairy cow. J. Anim. Sci. 73:2820-2833.

Grummer, R. R., J. C. Winkler, S. Bertics, and V. A. Studer. 1994 Effect of propilene glycol dosage during feed restriction on metabolites in blood of prepartum Holstein heifers. J. Dairy Sci. 77:3618-3623.

Johnson, M. M., and J. P. Peters. 1993. Technical Note: An improved method to quantify nonesterified fatty acids in bovine plasma. J. Anim. Sci. 71:753-756.

Kaneko, J. J. 1989. Appendixes. Pages 877-901 in Clinical Biochemistry of Domestic Animals. J. J. Kaneko, ed. Academic Press, San Diego, CA.

Kenelly, J. J., and K. A. Lien. 1997. Effect of ionophore supplementation on milk components from lactating cows. Pages 40-49 in Proc. Usefulness of ionophores in lactating dairy cattle, Ontario Veterinary College, Canada.

Laranja da Fonseca, L. F., C. S. Lucci, P. H. M. Rodrigues, M. V. Santos, and A. P. Lima. 1998. Supplementation of propylene glycol to dairy cows in periparturient period: effects on plasma concentration of BHBA, NEFA, and glucose. J. Anim. Sci. 76(Suppl. 1):320. (Abstr.)

Littell, R. C., P. R. Henry, and C. B. Ammerman. 1998. Statistical analysis of repeated measures data using SAS procedures. J. Anim. Sci. 76:1216-1231.

National Research Council. 1989. Nutrient Requirements of Dairy Cattle. 6th Ed. Natl. Acad. Sci., Washington, DC.

Petterson, J. A., R. Slepetis, R. A. Ehrhardt, F. R. Dunshea, and A. W. Bell. 1994. Pregnancy but not moderate under nutrition attenuates insulin suppression of fat mobilization in sheep. J. Nutr. 124:2431-2436.

Phipps, R. H., B. A. Jones, J. I. D. Wilkinson, and E. D. Tarrant. 1995. Effect of monensin on milk production of Friesian dairy cows in the United Kingdom. J. Dairy Sci. 78(Suppl. 1):268. (Abstr.)

Ramanzin, M., L. Baioloni, S. Schiavon, and G. Bittante. 1997. Effect of monensin on milk production and efficiency of dairy cows fed two diets differing in forage to concentrate rations. J. Dairy Sci. 80:1136-1142.

Russell, J. B. 1997. Mechanisms of action of ionophores. Pages 8892 in Proc. Cornell Nutrition Conference for Feed Manufactures, Cornell University, Ithaca NY.

SAS User's Guide: Statistics. 1991. Version 5 Edition. SAS Inst., Inc., Cary, NC.

Sauer, F. D., J. D. Erfle, and L. J. Fisher. 1973. Propylene glycol and glycerol as a feed additive for lactating dairy cows: an evaluation of blood metabolic parameters. Can. J. Anim. Sci. 53:265-271.

Sauer, F. D., J. K. G. Kramer, and W. J. Cantwell. 1989. Antiketogenic effects of monensin in early lactation. J. Dairy Sci. 72:436-442.

Stephenson, K. A., I. J. Lean, M. L. Hyde, M. A. Curtis, J. K. Garvin, and L. B. Lowe. 1997. Effects of monensin on the metabolism of periparturient dairy cows. J. Dairy Sci. 80:830-837.

Strum D. P., J. H. May, and L. G. Vargas. 2000. Modeling the uncertainty of surgical procedure times: comparison of log-normal and normal models. Anesthesiology 92:1160-1167.

Studer, V. A., R. R. Grummer, and S. J. Bertics. 1993. Effect of prepartum propylene glycol administration on periparturient fatty liver in dairy cows. J. Dairy Sci. 76:2931-2939. 
Thomas, E. E., S. E. Poe, R. K. Mcguffey, D. H. Mowrey, I. N. Greenfield, and R. D. Allrich. 1993. The effect of feeding monensin to dairy cows on milk production and serum metabolites during early lactation. J. Dairy Sci. 76(Suppl. 1):280. (Abstr.)

Tucker, A. H. 1985. Endocrine and Neural Control of the Mammary Gland. Pages 39-79 in Lactation. B. L. Larson, The Iowa State University Press, Ames, IA.

Van Der Werf, J. H. J., L. J. Jonker, and J. K. Oldenbroek. 1998 Effect of monensin on milk production by Holstein and Jersey cows. J. Dairy Sci. 81:427-433.
Van Soest, P. J., J. B. Robertson, and B. A. Lewis. 1991. Methods for dietary fiber, neutral detergent fiber, and nonstarch polysaccharides in relation to animal nutrition. J. Dairy Sci. 74:35833597.

Waldo, D. R., and L. H. Schultz. 1960. Blood and rumen changes following the intraruminal administration of glycogenic materials. J. Dairy Sci. 43:496-505.

Zammit, V. A. 1990. Ketogenisis in the liver of ruminants-adaptation to a challenge. J. Agric. Sci. 115:155-162. 